\title{
PERAN SAVE THE CHILDREN DALAM MENANGANI ANAK DISABILITAS DI BANDUNG
}

\author{
Oleh \\ Ria Agnes Chrisnalia Silalahi, Agus Wahyudi Riana, \& Nandang Mulyana
}

Email:

(Email: agnesria@gmail.com)

\begin{abstract}
ABSTRAK
Penelitian ini berjudul "Fungsi Save The Children Dalam Menangani Anak Disabilitas Di Bandung (Kelurahan Sukaluyu Kec. Cibeunying Kaler Kota Bandung)". Penelitian ini bertujuan untuk menggambarkan proses pelayanan yang diberikan oleh Save The Children dari tahap awal sampai berakhirnya program atau terminasi terhadap anak penyandang disabilitas di Kelurahan Sukaluyu Kec. Cibeunying Kaler Kota Bandung. Adapun pelayanan diberikan untuk menghasilkan anak yang berdaya dan mandiri dalam melakukan setiap hal di kehidupannya. Penelitian ini menggunakan pendekatan penelitian kualitatif dengan jenis penelitian deskriptif, sedangkan instrument yang digunakan dalam pengumpulan data adalah pedoman wawancara serta pedoma observasi dengan teknik wawancara mendalam dan observasi partisipatif. Informan dalam penelitian ini adalah pihak pemberi pelayanan dan dari pihak penerima program.
\end{abstract}

Kata kunci: pelayanan sosial. Anak. Disabilitas. Save The Children

\section{ABSTRAK}

This Research entitled "Functions Save The Children In Dealing Child Disability In Bandung" (Sukaluyu urban village district. Cibeunying Kaler Bandung City)". This research to describe the services provided by Save The Children from the beginning to the end of the program or termination of children with disabilities in Sukaluyu urban village district. Cibeunying Kaler Bandung City. The services are provided to produce a powerful and independent child in doing every things in his life. This research used a qualitative research approach with descriptive research. The instrument used in the data collection guidelines interviews and observations with in-depth interview techniques and participant observation. Informants in this research were from other service providers and people of the beneficiaries of the program.

Key words: social service. Children. Disability. Save The Children

\section{PENDAHULUAN}

Setiap anak memiliki hak yang sama dalam proses menjalani kehidupannya. Tidak peduli apakah seorang anak tersebut normal atau memiliki kebutuhan khusus. Setiap anak berhak untuk mendapatkan apa yang telah ditentukan sebagai haknya.
Berdasarkan Konvensi Hak Anak PBB Tahun 1989, ada 10 hak yang harus diberikan untuk anak-anak. Berikut di antaranya:

1) Hak untuk BERMAIN

2) Hak untuk mendapatkan PENDIDIKAN 
3) Hak untuk mendapatkan PERLINDUNGAN

4) Hak untuk mendapatkan NAMA (identitas)

5) Hak untuk mendapatkan status KEBANGSAAN

6) Hak untuk mendapatkan MAKANAN

7) Hak untuk mendapatkan akses KESEHATAN

8) Hak untuk mendapatkan REKREASI

9) Hak untuk mendapatkan KESAMAAN

10) 10. Hak untuk memiliki PERAN dalam PEMBANGUNAN

Anak berkebutuhan khusus atau anak dengan disabilitas sering kali kerap mendapatkan perlakuan diskriminatif dalam pemenuhan haknya. Di lingkungan masyarakatnya, anak dengan disabilitas sering kali mendapat perlakuan tidak adil. Tidak jarang pula anak dengan disabilitas mendapatkan perlakuan bullying dari lingkungan sosialnya. Mereka para penyandang disabilitas kerap dijadikan bahan olok-olok oleh teman sebayanya. Mereka juga dipandang sebelah mata oleh masyarakat, dianggap tidak bisa melakukan apa-apa.

Dengan perlakuan yang mereka terima, tidak menutup kemungkinan akan menjadikan anak dengan disabilitas menjadi tidak memiliki kepercayaan diri. Sehingga menghambat aktualisasi dirinya. Begitu pula dengan pemenuhan haknya yang ditakutkan akan terhambat.

Dukungan dari orang terdekat seperti keluarga menjadi sangat berharga untuk perkembangan anak dengan disabilitas. Dukungan dari keluarga akan membantu anak dengan disabilitas mengurangi kekhawatiran mereka dengan dunia luar yang tidak ramah dengan mereka.

Namun sangat disayangkan jika orang tua dari anak dengan disabilitas juga ikut mendiskriminasikan anak dengan disabilitas. Orang tua yang tidak menerima kondisi anaknya yang memiliki kebutuhan khusus sering kali menganggap anak dengan disabilitas sebagai beban keluarga. Tidak hanya itu, bahkan ada orang tua yang menganggap anak dengan disabilitas sebagai aib keluarga.

Lembaga pelayanan sosial yang bergerak di bidang anak Save The Children memiliki salah satu program yang berkaitan dengan anak dengan disabilitas. Program ini merupakan program pembinaan atau Rehabilitas Berbasis Masyarakat (RBM) untuk anak dengan disabilitas dan orang tua. Dalam program ini selain melakukan terapi kepada anak dengan disabilitas juga mengajarkan kepada orang tua bagaimana melakukan terapi mandiri kepada anaknya. Atas dasar uraian yang telah dipaparkan sebelumnya, peneliti tertarik untuk melakukan penelitian dengan pokok masalah fungsi Save The Children dalam menangani anak disabilitas di bandung (Kelurahan Sukaluyu Kec. Cibeunying Kaler Kota Bandung).

\section{KAJIAN PUSTAKA}

\section{DISABILITAS}

Penyandang disabilitas yang dalam percakapan sehari-hari disebut sebagai orang cacat, sering dianggap sebagai warga masyarakat yang tidak produktif, tidak mampu menjalankan tugas dan tanggung jawabnya sehingga hak-haknya pun diabaikan. Masih banyak masyarakat yang berlaku diskriminatif terhadap penyandang disabilitas. Padahal bila saja para penyandang disabilitas diberi kesempatan untuk beraktivitas dan berkarya, mereka pun dapat menghasilkan sesuatu yang bisa dibanggakan.

Disabilitas merupakan kelainan yang ada pada seseorang baik mental maupun fisik dan menghambat seseorang tersebut dalam beraktivitas. Kelainan yang dialami pada individu tertentu membuat seseorang sulit dalam mengerjakan sesuatu. Seseorang yang mengalami disabilitas biasanya membutuhkan 
bantuan baik dari orang lain ataupun benda yang dapat membantunya untuk melakukan kegiatan.

Jenis-jenis Disabilitas

\section{a. Tuna Netra}

Pengertian tuna netra tidak saja mereka yang buta, tetapi mencakup juga mereka yang mampu melihat tetapi terbatas sekali dan kurang dapat dimanfaatkan untuk kepentingan hidup sehari-hari terutama dalam belajar.

Anak tuna netra cenderung memiliki berbagai masalah baik yang berhubungan dengan masalah pendidikan, sosial, emosi, kesehatan, pengisian waktu luang maupun pekerjaan. Semua permasalahan tersebut pelu diantisipasi dengan memberikan layanan pendidikan, arahan, bimbingan, latihan, dan kesempatan yang luas bagi tuna netra sehingga permasalahan-permasalahan yang mungkin timbul dalam berbagai aspek tersebut dapat ditanggulangi sedini mungkin. Artinya perlu dilakukan upaya-upaya khusus secara terpadu dan multidisipliner untuk mencegah jangan sampai maslah tersebut muncul meluas dan mendalam, yang akhirnya dapat merugikan anak tuna netra tersebut.

\section{b. Tuna Rungu}

Tuna rungu dapat diartikan sebagai suatu keadaan kehilangan pendengaran yang mengakibatkan seseorang tidak dapat menangkap berbagai rangsangan, termasuk pendengaran.

Andreas Dwidjosumarto mengemukakan bahwa seseorang yang tidak atau kurang mampu mendengar suara dikatakan tunarungu. Ketunarunguan dibedakan menjadi dua kategori yaitu tuli (deaf) dan kurang dengar (low of hearing). Tuli adalah mereka yang indera pendengarannya mengalami kerusakan dalam taraf berat sehingga pendengaran tidak berfungsi lagi. Sedangkan kurang dengar adalah mereka yang indera pendengarannya mengalami kerusakan tetapi masih dapat berfungsi untuk mendengar, baik dengan maupun tanpa alat bantu dengar.

\section{c. Tuna Grahita}

Tuna Grahita/Cacat Ganda adalah kelainan dalam pertumbuhan dan perkembangan pada mental intelektual (mental retardasi) sejak bayi / dalam kandungan atau masa bayi dan anakanak yang disebabkan oleh faktor organik biologis maupun faktor fungsional, adakalanya disertai dengan cacat fisik dengan ciri-ciri dan klasifikasi sebagai berikut.

Ciri ciri Tuna Grahita antara lain :

1) Kecerdasan sangat terbatas.

2) Ketidakmampuan sosial yaitu tidak mampu mengurus diri sendiri, sehingga selalu memerlukan bantuan orang lain

3) Keterbatasan minat.

4) Daya ingat lemah.

5) Emosi sangat labil.

6) Apatis, acuh tak acuh terhadap sekitarnya.

7) Kelainan badaniah khusus jenis mongoloid badan bungkuk, tampak tidak sehat, muka datar, telinga kecil, badan terlalu kecil, kepala terlalu besar, mulut melongo, mata sipit.

\section{d. Tuna Daksa}

Penyandang disabilitas yang mempunyai hambatan dengan bagian tubuh (tulang, otot, sendi) disebut tuna daksa. Menurut UndangUndang No. 4 Tahun 1997, Tuna Daksa adalah seorang yang mempunyai kelainan atau gangguan pada alat gerak yang meliputi tulang, otot dan persendian baik dalam struktur dan atau fungsinya, sehingga tidak dapat melakukan kegiatan secara wajar.

Adapun Ciri-cirinya yaitu:

a) anggota tubuh tidak lengkap, putus atau amputasi tungkai, lengan atau kaki,

b) cacat tulang atau persendiaan,

c) (c) cacat sendi otot dan tungkai, lengan atau kaki, dan 
d) lumpuh

\section{e. Tuna Laras}

Tunalaras adalah individu yang mengalami hambatan dalam mengendalikan emosi dan kontrol sosial. Individu tunalaras biasanya menunjukan perilaku menyimpang yang tidak sesuai dengan norma dan aturan yang berlaku di sekitarnya. Tunalaras dapat disebabkan karena faktor internal dan faktor eksternal yaitu pengaruh dari lingkungan sekitar.

Menurut T.Sutjihati Somantri, (2007 : 139) “ Anak tunalaras sering juga disebut anak tunasosial karena tingkah laku anak ini menunjukkan penentangan terhadap normanorma sosial masyarakat yang berwujud seperti mencuri, mengganggu, dan menyakiti orang lain." Individu tunalaras biasanya menunjukan perilaku menyimpang yang tidak sesuai dengan norma dan aturan yang berlaku di sekitarnya.

\section{KELUARGA}

Menurut Salvicion dan Celis (1998) di dalam keluarga terdapat dua atau lebih dari dua pribadi yang tergabung karena hubungan darah, hubungan perkawinan atau pengangkatan, di hidupnya dalam satu rumah tangga, berinteraksi satu sama lain dan di dalam perannya masing-masing dan menciptakan serta mempertahankan suatu kebudayaan. Baron. R. A dan Donn Byrne. 2003. Psikologi Sosial. Jakarta: Erlangga

Ada beberapa jenis keluarga, yakni: keluarga inti yang terdiri dari suami, istri, dan anak atau anak-anak, keluarga konjugal yang terdiri dari pasangan dewasa (ibu dan ayah) dan anakanak mereka, di mana terdapat interaksi dengan kerabat dari salah satu atau dua pihak orang tua. Selain itu terdapat juga keluarga luas yang ditarik atas dasar garis keturunan di atas keluarga aslinya. Keluarga luas ini meliputi hubungan antara paman, bibi, keluarga kakek, dan keluarga nenek..

\section{PELAYANAN SOSIAL}

Pelayanan sosial merupakan berbagai program yang dirancang untuk memenuhi kebutuhan sosial individu, keluarga, dan kelompok, merupakan komponen penting dari wilayah perkotaan. Umumnya, layanan sosial adalah program-program yang mempekerjakan pekerja sosial atau profesional terkait dan diarahkan ke arah pencapaian tujuan kesejahteraan sosial. Sebuah definisi yang berbeda menggambarkan pelayanan sosial sebagai manfaat berwujud yang disediakan oleh badan-badan dan lembaga untuk memperbaiki disfungsi sosial dan mencegah masalah di fungsi sosial. Kedua definisi menghubungkan layanan sosial untuk bidang yang lebih luas pelayanan kesejahteraan sosial, yang umumnya dianggap upaya masyarakat untuk memenuhi kebutuhan dasar manusia seperti pendapatan, perumahan, pendidikan, perawatan kesehatan, dan pekerjaan. Pelayanan sosial meliputi konseling, informasi dan rujukan, pendidikan, sosialisasi, dan program kelompok rehabilitatif, serta layanan dukungan terkait. Pelayanan sosial adalah aktivitas yang terorganisasi yang bertujuan untuk membantu masyarakat untuk saling menyesuaikan diri dengan sesamanya dan dengan lingkungan sosialnya.

Selanjutnya, Alfred J. Khan memberikan pengertian pelayanan sosial sebagai berikut:

Pelayanan sosial terdiri dari programprogram yang diadakan tanpa memertimbangkan kriteria pasar untuk menjamin suatu tingkatan dasar dalam penyediaan fasilitas pemenuhan kebutuhan akan kesehatan, pendidikan, dan kesejahteraan untuk meningkatkan kehidupan masyarakat serta kemampuan perorangan untuk pelaksanaan fungsi-fungsinya, untuk memperlancar kemampuan menjangkau dan menggunakan pelayanan-pelayanan serta lembagalembaga yang telah ada dan membantu warga masyarakat yang mengalami kesulitan dan keterlantaran" 


\section{DAFTAR PUSTAKA}

Dra. Hj. T. Sutjihati Somantri, M.Si., psi. 2006. Psikologi Anak Luar Biasa. Bandung: PT. Refik Aditama

Prof. Dr. Bandi Delphie, M.A., S.E.2006. Pembelajaran Anak Berkebutuhan Khusus. Bandung: PT. Refik Aditama
Ronald. 2006. Peran Orang Tua dalam meningkatkan kualitas hidup, mendidik dan mengembangkan moral anak. Bandung: CV. Yrama Widya

Richard R Clayton. 2003. The Family, Mariage and Social Change. hal. 58

Anita L. Vangelis.2004.Handbook of Family Comunication.USA:Lawrence Elbraum Press. hal 349.

Jhonson, C.L. 1988. Ex Familia. New Brunswick: Rutger University Press 